\title{
Socio-Economic Hardship, Psychological Health and Human Wellbeing in Nigeria: A Southeast Study
}

\author{
Obidigbo Godwin Chekwubechukwu \\ Department of Psychology, Faculty of Social Sciences, Nnamdi Azikiwe University, Awka, Nigeria
}

\section{Email address:}

obidigbog@yahoo.com

\section{To cite this article:}

Obidigbo Godwin Chekwubechukwu. Socio-Economic Hardship, Psychological Health and Human Wellbeing in Nigeria: A Southeast Study. American Journal of Applied Psychology. Vol. 10, No. 4, 2021, pp. 89-94. doi: 10.11648/j.ajap.20211004.11

Received: June 21, 2021; Accepted: July 1, 2021; Published: July 13, 2021

\begin{abstract}
The literature is dominant with findings that financial crisis and socioeconomic stressors lead to psychological disorder and physical ill health. None of the available studies was conducted in Nigeria, particularly in the Southeast region. This paper investigates if: socio-economic hardship and stressors have any significant impact on people's psychological health and well-being; and if the impact of socio-economic hardship and stressors on people's psychological health and well-being have social policy and environmental buffer in Southeast Nigeria. Researcher's modelled questionnaire was used to generate data from a sample of 1000 respondents (male $=521$ and females $=479)$ drawn from the capitals of the five states in Southeast Nigeria. The analysis of data generated was carried out with the aid of tables, \% formula, and Statistical Package for Social Sciences (SPSS) version 20.0 for purposes of determining their mean and standard deviation, and for descriptive purposes. Results of the analysis reveal high-level prevalence of financial crisis and socioeconomic stressors in the region that tend to influence respondents' psychological health and well-being through anxiety and stress. Among others, it reveals also the efficacy of religious activities and doctrinal teachings together with illegal sources of incomes as effective buffers to the potential negative impact. The study concludes that financial crisis and socioeconomic stressors have potential negative impacts on people's psychological health and well-being in Southeast Nigeria, however, religious activities and doctrinal teachings together with illegal sources of incomes serve as buffers to this impact. The significance of these findings lay in their drive to introduce effective social policy and establish institutionalised professional counselling services across the region.
\end{abstract}

Keywords: Hardship, Socioeconomic Stressors, Psychological Health, Human Well-Being, Buffer

\section{Introduction}

Financial crisis, decline in economic growth, and recession are historical experiences that have continued to cause rising rate of unemployment, job loss, currency devaluation, poverty, and hardship among people in the Less Developing Countries (LDCs) particularly Nigeria. In such financial crisis, hardship emerges from individuals' perception of inherent financial constraints and/or expectation of future financial problems [21], which translates into emotional disorder or psychological ill health/problems. On the other hand, favourable income and wealth allow individuals to satisfy their needs and sustain preferential choices of commodities and services over time, which enhances their freedom, psychological state of living, and well-being [14].

The concept of wellbeing is a complex and multifactorial construct whose definition and measurement are sometimes divided into objective trajectory i.e. focuses on the standard of living, and subjective trajectory i.e. focuses on cognitive and affective judgements individuals make about their lives such as individual perceptions concerning psychological, social, and spiritual issues [22].

A holistic construct of the concept then refers the totality of life satisfaction that is imbedded in the quality of life one experiences. This encapsulates the level of satisfaction of human needs, and the state of mental and physical health such as absence or prevalence stress, functioning/disability status, and physical symptoms [6, 19]. It is, therefore, a psychosocial concept that expresses people's perception of the conditions of their lives, whether it is good or not. Thus, good living conditions, satisfaction/positive emotions and resilience, and excellent health status are fundamental to human well-being [7, 8]. Well-being is associated with multiple health, job, family, and economically related 
beneficial status.

Thus, financial hardship limits individual freedom to satisfy needs, generates negative emotions, and orchestrates depression, which subjects such individual to deplorable condition and subjective actions if policy interventions are non-existent $[13,17]$. It is a precursor to stress, anxiety, and depression that translate to poor health, disease, psychotic disorder, and even suicide. It has equally led people to adopt unhealthy behaviours such as excessive smoking, drug, and alcohol abuse [29, 24]. Scholars are of the opinion that financial hardship equally intensifies personal strain that inhibit the recovery process in situations of ill health $[2,27]$. Thus, hardship and poor psychological health influence or affect people's physical health.

Hardship has an effect on people's thinking and behaviour, which may in turn influence their physical health. For instance, alcoholism and substance abuse by many people, especially men, are means of coping with emotional problems generated most times by hardship [1, 3]. Scholars call the nexus between hardship, psychological health, and human well-being 'psychophysiological triangle', involving communication between the central nervous system, the immune system, and the endocrine system. From this, hardship leads to low levels of psychological health, which leads to a reduced/weaker immune response or defences against diseases and infection, and high levels of stress leading to higher levels of inappropriate endocrine activity $[3,16]$.

Empirical studies reveal differential levels of negative impacts of financial hardship on people's psychological health and well-being in places like Greece, Ireland, Bangladesh, Germany, and the United States among others $[9,26,25,28,11,20,4]$. The literature attributes the differential impacts to different social policy contexts, and legal and cultural contexts in these countries that tend to influence how individuals cope life demands [5, 12, 10, 23].

Although avalanche of research exist in the literature on the influence or impact of socio-economic hardship on psychological health and human wellbeing, their findings are characteristically different due to prevailing social policy contexts, and legal and cultural contexts in the countries where the research were conducted. Further, none of the existing research was conducted in Nigeria particularly Southeast whose social policies, and legal and cultural contexts vary from others. Consequently, this article pursues answers to the following research questions:

i. Has socio-economic hardship any significant impact of people's psychological health and well-being in Southeast Nigeria?

ii. Does the impact of socio-economic hardship on people's psychological health and well-being have social policy and environmental buffer in Southeast Nigeria?

\section{Materials and Methods}

\subsection{Research Design}

A cross sectional survey study was carried out in the five states of Southeast Nigeria from February to May 2021. The locations of the study were the state capitals of the five states, namely: Awka in Anambra state, Abakiliki in Ebonyi state, Enugu in Enugu state, Owerri in Imo state, and Umuahia in Abia state.

\subsection{Sources and Instruments of Data Collection}

The research explored primary sources of data collection using a 2021 researcher-structured questionnaire to generate data from 1000 respondents. Response to questions was organized on a five likert-like options format of Strongly Agree, Agree, Undecided, Disagree and Strongly Disagree with scoring pattern as follow: Strongly Agree $=5$ points; Agree $=4$ points; Undecided $=3$ points; Disagree $=2$ points; Strongly Disagree $=1$ point. To complement the primary source, secondary sources of data such as relevant and accessible textbooks, journals, conference and workshop papers, and internet materials were explored.

\subsection{Sample Size}

A total 1000 adult respondents (comprising of 560 males and 440 females) of $\geq 18$ years of age were randomly selected as the study sample. The study sample was drawn from churches, mosques, civil service, and markets in the various locations of the study. These areas were chosen because all strata of the society are always present in these areas.

Inclusion criteria:

1) Human beings who are present during the field work

2) Either sex

3) Aged $\geq 18$ years

4) Demonstrated willingness to participate in the research Exclusion criteria:

1) Mentally incapacitated individuals with genetic disorders

2) Very busy people during the data collection

3) People that could neither write nor speak

4) Those who are not willing to participate in the inquiry

\subsection{Validity and Reliability of Instrument of Data Collection}

4 evaluators comprising of 2 psychologists, a medical professional, a lecturer from the Department of Sociology, Nnamdi Azikiwe validated the instrument. Any item in the questionnaire that did not have $80 \%$ acceptance by the evaluators was discarded. Further, Test re-test method was used to measure the reliability of the instrument. 20 copies of the questionnaires were administered to similar respondents and setting at Onitsha in Anambra state and Nsukka in Enugu state. After an interval of three weeks, the questionnaires were re-administered to the same respondents. The two set of responses obtained were correlated using the Pearson Product Moment Correlation ( $r$ ) and a co-efficient of reliability of 0.95 was obtained. This shows that the instrument is reliable for data collection. 


\subsection{Data Analysis}

In pursuit of central tendencies, mean, and deviations, the data generated was analysed using tables, percentage formula, and SPSS version 20 (SPSS Inc., Chicago, IL). Decision were taken based on the standard that mean difference is significant at $\geq 0.05$.

\section{Results}

\subsection{Socio-demographic Characteristics of Respondents}

992 out of 1000 respondents (consisting of 521 males and 479 females) returned well completed questionnaire from the five state capitals in Southeast thereby recording a response rate of $99.2 \%$. Majority of the respondents belonged to 28-37 age group with $52.38 \%$, while employed category constitutes $63.07 \%$ i.e. 626 respondents, pensioner category constitutes $11.05 \%$ i.e. 110 respondents and $25.88 \%$ i.e. 256 respondents constituting unemployed. $68.94 \%$ i.e. 684 of the respondents earn less than N100,000.00 i.e. \$206 monthly while $46.75 \%$ i.e. 464 respondents are family bread winners. The critical factors that generate anxiety among the respondents during hardship were identified as unemployment $(27.01 \%)$, low or inadequate income $(23.34 \%)$, young age of $<25$ years and uncertainties about life $(21.0 \%)$, businesses and price fluctuations (18.09\%), and low or no education (10.66\%).

\subsection{Socio-economic Hardship and People's Psychological Health and Well-Being in Southeast Nigeria}

Table 1. Results of SPSS Analyses of responses to questions.

\begin{tabular}{|c|c|c|c|c|c|c|c|}
\hline Sn & Research questions & $\begin{array}{l}\text { Grand } \\
\text { Mean }\end{array}$ & $\begin{array}{l}\text { Standard } \\
\text { Deviation }\end{array}$ & $\begin{array}{l}\text { Standard } \\
\text { Error }\end{array}$ & $\begin{array}{l}\text { Tests of Between- } \\
\text { Subjects Effects }\end{array}$ & Sig. & Pairwise Comparisons \\
\hline 1 & $\begin{array}{l}\text { Your monthly income is commensurate with the } \\
\text { daily rising prices of commodities and services }\end{array}$ & 2.30 & 1.300 & .074 & 454.700 & .000 & $\begin{array}{l}\text { (a) } 95 \% \text { confidence } \\
\text { Interval, no adjustments }\end{array}$ \\
\hline 2 & $\begin{array}{l}\text { The means of satisfying your needs and that of the } \\
\text { family is a source of anxiety to you }\end{array}$ & 4.21 & 1.109 & .156 & 62.673 & .003 & $\begin{array}{l}\text { (a) } 95 \% \text { confidence } \\
\text { Interval, no adjustments }\end{array}$ \\
\hline 3 & $\begin{array}{l}\text { There are opportunities for unexpected income in } \\
\text { your line of business or official duties that assist in } \\
\text { satisfying your needs }\end{array}$ & 2.58 & .239 & .241 & 240.296 & .000 & $\begin{array}{l}\text { (a) } 95 \% \text { confidence } \\
\text { Interval, no adjustments }\end{array}$ \\
\hline 4 & $\begin{array}{l}\text { Daily increases in prices of commodities, inadequate } \\
\text { food supply, children's educational loss, and payment } \\
\text { of house rent have been causing you anxiety and/or } \\
\text { depressive symptoms }\end{array}$ & 4.14 & .918 & .056 & 226.652 & $\begin{array}{l}.262 \\
\& \\
.000\end{array}$ & $\begin{array}{l}\text { (a) } 95 \% \text { confidence } \\
\text { Interval, no adjustments }\end{array}$ \\
\hline 5 & $\begin{array}{l}\text { You are suffering from severe anxiety and high blood } \\
\text { pressure }\end{array}$ & 2.31 & 1.042 & .050 & 143.223 & .000 & $\begin{array}{l}\text { (a) } 95 \% \text { confidence } \\
\text { Interval, no adjustments }\end{array}$ \\
\hline 6 & $\begin{array}{l}\text { You are suffering from mild or low anxiety and } \\
\text { incessant ill-health leading to regular medication }\end{array}$ & 2.09 & .345 & .058 & 189.002 & .000 & $\begin{array}{l}\text { (a) } 95 \% \text { confidence } \\
\text { Interval, no adjustments }\end{array}$ \\
\hline 7 & $\begin{array}{l}\text { You are a victim of neurosis and other forms of } \\
\text { psychological ill health }\end{array}$ & 2.31 & 1.042 & .050 & 143.223 & .000 & $\begin{array}{l}\text { (a) } 95 \% \text { confidence } \\
\text { Interval, no adjustments }\end{array}$ \\
\hline
\end{tabular}

Source: SPSS analysis of responses to questions

A review of table 1 above reveals that majority of the 992 respondents disagreed with statements in questions I, 3, 5, 6, \& 7, which sought to find out if: a) Respondents monthly incomes are commensurate with the daily rising prices of commodities and services; b) There are opportunities for unexpected income in respondents' line of business or official duties that assist in satisfying their needs; c) Respondents are suffering from severe anxiety and high blood pressure; d) Respondents are suffering from mild or low anxiety and incessant ill-health leading to regular medication; and e) Respondents are a victim of neurosis and other forms of psychological ill health.

The SPSS analysis of their responses to each of the statement reveals grand means of between 2.09 to 2.58 with standard deviations whose levels of differences are insignificant when compared with.05 standard level of significance. Their Pairwise Comparisons reveal no adjustment. Thus, the ground means of between 2.09 to 2.58 representing 'Disagree' in our likert scale measure are accepted. Therefore, majority of the respondents are experiencing financial crisis and other socio-economic stressors yet they are not suffering from any form of psychological ill health and incessant ill health leading to regular medication.

Further review of table 1 reveals that majority of the 992 respondents agreed with statements in questions $2 \& 4$, which sought to find out if: a) the means of satisfying respondents' needs and that of their families are sources of anxiety; and b) Daily increases in prices of commodities, inadequate food supply, children's educational loss, and payment of house rent have been causing anxiety and/or depressive symptoms in the lives of the respondents.

The SPSS analysis of their responses to each of the statement in $2 \& 4$ reveals grand means of $4.21 \& 4.14$ with standard deviations whose levels of differences are insignificant when compared with.05 standard level of significance. Their Pairwise Comparisons equally reveal no adjustment. Thus, the ground means of between $4.21 \& 4.14$ representing 'Agree' in our likert scale measure are accepted. Therefore, income generation, daily increases in prices of commodities, inadequate food supply, children's educational loss, and payment of house rent are sources of anxiety and stress for majority of the respondents. 


\subsection{Impact of Socio-economic Hardship and Social Policy and Environmental Buffers in Southeast Nigeria}

Table 2. Results of SPSS Analyses of responses to questions.

\begin{tabular}{|c|c|c|c|c|c|c|c|}
\hline Sn & Research questions & $\begin{array}{l}\text { Grand } \\
\text { Mean }\end{array}$ & $\begin{array}{l}\text { Standard } \\
\text { Deviation }\end{array}$ & $\begin{array}{l}\text { Standard } \\
\text { Error }\end{array}$ & $\begin{array}{l}\text { Tests of Between- } \\
\text { Subjects Effects }\end{array}$ & Sig. & Pairwise Comparisons \\
\hline 1 & $\begin{array}{l}\text { Government rolled out intervention programmes that } \\
\text { reduced the impact of socio-economic hardship on you }\end{array}$ & 2.30 & 1.300 & .074 & 454.700 & .000 & $\begin{array}{l}\text { (a) } 95 \% \text { confidence } \\
\text { Interval, no adjustments }\end{array}$ \\
\hline 2 & $\begin{array}{l}\text { Religious activities and doctrinal teachings altered } \\
\text { your perception and reduced the anxiety and } \\
\text { depression associated with socio-economic hardship }\end{array}$ & 4.21 & 1.109 & .156 & 62.673 & .003 & $\begin{array}{l}\text { ( } 95 \% \text { confidence } \\
\text { Interval, no adjustments }\end{array}$ \\
\hline 3 & $\begin{array}{l}\text { You opted for illegal means of solving } \\
\text { socioeconomic problems associated with prevailing } \\
\text { hardship }\end{array}$ & 4.44 & .949 & .058 & 242.430 & $\begin{array}{l}.042 \\
\& \\
.000\end{array}$ & $\begin{array}{l}\text { ( } 95 \% \text { confidence } \\
\text { Interval, no adjustments }\end{array}$ \\
\hline 4 & $\begin{array}{l}\text { Loans and financial securities provided alternative } \\
\text { means of solving your financial problems and } \\
\text { satisfying your needs }\end{array}$ & 2.31 & 1.042 & .050 & 143.223 & .000 & $\begin{array}{l}\text { (a) } 95 \% \text { confidence } \\
\text { Interval, no adjustments }\end{array}$ \\
\hline 5 & $\begin{array}{l}\text { Counselling services built a positive perception that } \\
\text { made you happy in the midst of hardship }\end{array}$ & 2.09 & .345 & .058 & 189.002 & .000 & $\begin{array}{l}\text { (a) } 95 \% \text { confidence } \\
\text { Interval, no adjustments }\end{array}$ \\
\hline 6 & $\begin{array}{l}\text { Philanthropist gestures and extended family assistance } \\
\text { gave you succour from prevailing hardship }\end{array}$ & 2.09 & .345 & .058 & 189.002 & .000 & $\begin{array}{l}\text { (a) } 95 \% \text { confidence } \\
\text { Interval, no adjustments }\end{array}$ \\
\hline
\end{tabular}

Source: SPSS analysis of responses to questions.

A review of table 2 above reveals that majority of the 992 respondents disagreed with statements in questions $\mathrm{I}, 4,5, \&$ 6 , which sought to find out if: a) Government rolled out intervention programmes that reduced the impact of socioeconomic hardship on respondents; b) Loans and financial securities provided alternative means of solving respondents' financial problems and satisfying their needs; c) Counselling services built a positive perception that made the respondents happy in the midst of hardship; and d) Philanthropist gestures and extended family assistance gave respondents succour from prevailing hardship.

The SPSS analysis of their responses to each of the statement reveals grand means of between 2.09 to 2.31 with standard deviations whose levels of differences are insignificant when compared with.05 standard level of significance. Their Pairwise Comparisons reveal no adjustment. Thus, the ground means of between 2.09 to 2.31 representing 'Disagree' in our likert scale measure are accepted. Therefore, government social policy, loan/credit facilities, counselling services, and philanthropies do not provide buffer for the impact of financial and socio-economic stressors on respondents' psychological health and well-being.

However, further review of table 2 reveals that majority of the 992 respondents agreed with statements in questions 2 \& 3 , which sought to find out if: a) religious activities and doctrinal teachings altered respondents' perception and reduced the anxiety and depression associated with socioeconomic hardship; and b) respondents' opted for illegal means of solving socioeconomic problems associated with prevailing hardship.

The SPSS analysis of their responses to each of the statement in $2 \& 4$ reveals grand means of $4.21 \& 4.44$ with standard deviations whose levels of differences are insignificant when compared with.05 standard level of significance. Their Pairwise Comparisons equally reveal no adjustment. Thus, the ground means of between $4.21 \& 4.44$ representing 'Agree' in our likert scale measure are accepted. Therefore, religious activities and doctrinal teachings together with illegal sources of income provided buffers for the impact of financial and socio-economic stressors on respondents' psychological health and well-being.

\section{Findings and Discussion}

The findings of the present study indicate that financial inability to satisfy life needs such as feeding, shelter, children education, and other essential needs, is a source of anxiety and depressive symptoms among majority of the respondents. The findings agree with previous studies $[9,25,20]$ that financial crisis and socio-economic stressors are precursors of both anxiety and depression. However, the findings of this study indicate a clear downward trend in the prevalence of anxiety and depressive symptoms in Southeast Nigeria in spite of the prevailing financial crisis and socio-economic stressor when compared to the findings of similar studies previously conducted in other cultures and countries $[24,28,16]$.

The perceived anxiety and depressive symptoms are infinitesimal to cause any form of psychological ill health and physical sickness due to the influence of religious activities and doctrinal teachings, and illegal sources of income, which served as buffer to the impact or influence of financial hardship on their psychological health and wellbeing. Unlike previous studies conducted in more than 53 countries [18], social policy, legal and cultural contexts are ineffective buffer to the impact of financial crisis and socioeconomic stressors on the psychological health and well-being of the respondents.

Further, this study identifies the critical factors that generate anxiety among the respondents during hardship as unemployment $(27.01 \%)$, low or inadequate income (23.34\%), young age of $<25$ years and uncertainties about life $(21.0 \%)$, businesses and price fluctuations $(18.09 \%)$, and 
low or no education $(10.66 \%)$. Thus, it appears that financial crisis and socio-economic stressors appear less depressing to adults of older age due to maturity and experiences that enable them to balance the vicissitudes of life more than the younger ones [14].

\section{Conclusion}

In Southeast Nigeria, financial crisis and socioeconomic stressors associated with prevailing hardship are potential sources of anxiety, stress, and psychological ill health among majority of the residents. Majority of them are underemployed with consequences of low income while $25.88 \%$ of the population are unemployed. Thus, the problems of rising prices of commodities and services, inadequate food supply, children's educational loss, and non-payment of house rent among others prevail among them. These tend to generate anxiety, stress, and psychological ill health predominantly among people of young age $(<25$ years $)$ due to uncertainties about life and the future, business entrepreneurs due to price fluctuations, the unemployed, and the uneducated.

The findings of this research show that there are no social policy programmes, philanthropic activities, professional counselling activities, or even loans/credit facilities floated to mitigate the impact of the observed financial and socioeconomic stressors on the psychological health and well-being of the residents. However, religious activities and doctrinal teachings, and engagement in illegal sources of income provided buffers for the said negative impacts. The implication of these findings for the prevailing increase of insecurity and monumental crimes of different nature is that government's anti-crime and pro-security programmes are bound to fail if efficient and efficacious socioeconomic intervention programmes are not floated. Consequently, strong macro-economic frameworks, and relevant efficient social policy intervention programmes are required to address the increasing hardship associate with financial crisis in the lives of residents of Southeast Nigeria. Institutionalised professional counselling services should be established in the region. This study recommends further research on the availability and impact of public policy intervention on financial crisis and socio-economic stressors as buffer.

\section{Author's Declaration}

\section{Ethics and Consent to Participate}

Ethical standards were maintained whilst the study was conducted. All participants voluntarily agreed to participate in the study after understanding the context of the Consent Form.

\section{Declaration of Conflict of Interest}

The authors declare that they have no competing interests.

\section{Acknowledgements}

The author hereby acknowledges the role played by research participants who voluntarily offered their time, and provided honest and thoughtful responses to the questions posed towards the conclusion of this inquiry. All authors whose works were used and referenced in the course of this research, are equally appreciated.

\section{References}

[1] Akerlind, I. \& Hornquist, J. O. (1992). Loneliness and alcohol abuse: a review of evidences of interplay. Social Science Medcine, 34, 405-414.

[2] Baron, R. A., Franklin, R. J., \& Hmieleski, K. M. (2013). Why entrepreneurs often experience low, not high levels of stress: The joint effects of selection and psychological capital. Journal of Management. doi: $10.1177 / 0149206313495411$.

[3] Bartlett, C. J. \& Coles, E. C. (1998). Psychological health and well-being: why and how should public health specialists measure it? Part 1: rationale and methods of the investigation, and review of psychiatric epidemiology. Journal of Public Health Medicine, 20 (3), 281-287.

[4] Burgard, S. A. \& Kalousova, L. (2015). Effects of the Great Recession: Health and well-being. Annual Review of Sociology, 41, 181-201.

[5] Casper, W. J., Allen, T. D., \& Poelmans, S. A. Y. (2014). International perspectives on work and family: An introduction to the special section. Applied Psychology: An International Review, 63, 1-4.

[6] Centers for Disease Control and Prevention (2018). Wellbeing concepts. Available @ https://www.cdc.gov/hrqol/wellbeing.htm\#eight.

[7] Diener, E. (2009). Assessing well-being: the collected works of Ed Diener. New York: Springer.

[8] Diener, E. \& Seligman, M. E. (2004). Beyond money. Toward an economy of well-being. Psychological Science in the Public Interest, 5 (1), 1-31.

[9] Economou, M., Madianos, M., Peppou, L. E., Patelakis, A., \& Stefanis, C. N. (2013). Major depression in the era of economic crisis: A replication of a cross-sectional study across Greece. Journal of Affective Disorders, 145. 308-314. doi: 10.1016/j.jad.2012.08.008

[10] Gudmundsdottir, D. G. (2013). The impact of economic crisis on happiness. Social Indicators Research, 110, 1083-1101.

[11] Jenkins, S. P., Brandolini, A., Micklewright, J., \& Nolan, B. (Eds., 2013). The Great Recession and the Distribution of Household Income. Oxford University Press.

[12] Kiely, K. M., Leach, L. S., Olesen, S. C. \& Butterworth, P. (2015). How financial hardship is associated with the onset of mental health problems over time. Social Psychiatry and Psychiatric Epidemiology, 50, 909-918.

[13] McDaid, D., Quaglio, G., De Campos, C. A., Dario, C., Van Woensel, L., Karapiperis, T., \& Reeves, A. (2013). Health protection in times of economic crisis: Challenges and opportunities for Europe. Journal of Public Health Policy, 34, 489-501. 
[14] Mirowsky, J., \& Ross, C. E. (2001). Age and the effect of economic hardship on depression. Journal of Health and Social Behaviour, 42 (2), 132-150.

[15] OECD (2013). Framework for statistics on the distribution of household income, consumption and wealth. Available@ http://www.oecd.org/ statistics/OECD-ICW-FrameworkChapter2.pdf

[16] Pelletier, K. R. (1992). Mind-body health: research, clinical and policy applications. American Journal of Health Promotion, 6, 345-358.

[17] Pollack, J. M., Vanepps, E. M., \& Hayes, A. F. (2012). The moderating role of social ties on entrepreneurs' depressed affect and withdrawal intentions in response to economic stress. Journal of Organizational Behavior, 33, 789-810.

[18] Rai, A. N., Vargas, M. L., Wang, L., Andersen, E. F., Miller, E. L., Simon, J. A. (2013). Elements of the Polycomb Repressor SU (Z) 12 Needed for Histone H3-K27 Methylation, the Interface with $\mathrm{E}(\mathrm{Z})$, and In Vivo Function. Mol. Cell. Biol. 33 (24): 4844--4856.

[19] Salvador-Carulla, L., Lucas, R., Ayuso-Mateos, J. L., \& Miret, M. (2014). Use of the terms "wellbeing" and "quality of life" in health sciences: a conceptual framework. European Journal of Psychiatry, 28 (1), 50-65.

[20] Santini, Z. I. et al., (2020). Social disconnectedness, perceived isolation, and symptoms of depression and anxiety among older Americans (NSHAP): A longitudinal mediation analysis. Lancet Public Health 5, e62-e70.

[21] Schieman, S., \& Young, M. (2011). Economic hardship and family-to-work conflict: The importance of gender and work conditions. Journal of Family and Economic Issues, 32, 4661. doi: 10.1007/s10834-010-9206-3.

[22] Schulte, P. A., Guerin, R. J., Schill, A. L., Bhattacharya, A., et al. (2015). Considerations for incorporating "well-being" in public policy for workers and workplaces. American Journal of Public Health, 105 (8), e31-44.

[23] Sinclair, R., Sears, L. E., Probst, T., \& Zajack, M. (2010). A multilevel model of economic stress and employee well-being. Contemporary Occupational Health Psychology: Global Perspectives on Research and Practice, 1, 1-20.

[24] Smith, R., \&. Mcelwee, G. (2011). After the fall: Developing a conceptual script-based model of shame in narratives of entrepreneurs in crisis. International Journal of Sociology and Social Policy, 31, 91-109.

[25] Sultana, S., Khan, A. H., Hossain, S., Islam, T., Hasan, M. T., Ahmede, H. U., \& Khanf, J. A. M. (2020). The association between financial hardship and mental health difficulties among adult wage earners during the COVID-19 pandemic in Bangladesh: Findings from a cross-sectional analysis. Available

https://www.researchgate.net/publication/344217979

[26] Walsch, B. (2011). Well-being and economic conditions in Ireland (No. 11/27). Working Paper Series. UCD Centre for Economic Research.

[27] Weller, S. A. (2012). Financial stress and the long-term outcomes of job loss. Work, Employment \& Society, 26, 10 25 .

[28] Witteveen, Dirk \& Velthorst, Eva (2020). Economic hardship and mental health complaints during COVID-19. Available @ https://doi.org/10.1073/pnas. 2009609117.

[29] World Health Organization. (2011). Impact of economic crises on mental health. WHO library cataloguing in publication data. Available @ http://www.euro.who.int/en/healthtopics/noncommunicable-diseases/mentalhealth/publications/2011/impact-of-economic-crises-onmental-health. 